\title{
The usefulness of ultrasound in the diagnosis of patients after chest trauma - two case reports
}

\author{
Agnieszka Popiel, Wojciech Siwiera, Adam Jerzy Białas \\ Department of Surgery, Wyszynski Memorial Hospital, Sieradz, Poland \\ Kardiochirurgia i Torakochirurgia Polska 2015; 12 (4): 372-376
}

\begin{abstract}
The effectiveness of ultrasound in diagnosing fractures of the ribs and sternum has been confirmed in the literature. The aim of our study was to present two case reports of patients with chest trauma history in whom ultrasound examination proved useful in the diagnostic process. The role of thoracic ultrasound in the diagnosis of ribs and sternal fractures is discussed as well. The authors conclude the following: 1) the examination was easy to perform and assess, and provided clinically useful conclusions; 2) due to the mobility of the ultrasound machine, the examination may be carried out outside of radiology departments, e.g. by the patient's bedside - in departments of surgery; 3) ultrasound should be the examination of choice after chest trauma and can be performed successfully by non-radiologist physicians.
\end{abstract}

Key words: ultrasound, rib fractures, sternal fracture, pneumothorax.

\section{Introduction}

Widely employed in modern medicine, ultrasound (US) has proven its use in many medical specialties. However, ultrasound diagnosis of bone fractures arouses a great deal of controversy. It was rib fractures that were the first bone fractures to be assessed by ultrasound. Since then, many authors have reported that rib fractures are better visible on ultrasound than on standard X-ray images. Moreover, the high effectiveness of US in diagnosing sternal fractures has been confirmed by relevant literature. The diagnosis of rib and sternal fractures is rarely discussed in Polish publications.

The aim of our study was to present two case reports; in both of them ultrasound examination proved useful in diagnosing patients who had suffered chest trauma.

\section{Material and methods}

The material consisted of two patients hospitalised in the Department of Surgery at the Wyszynski Memorial

\section{Streszczenie}

Efektywność ultrasonografii w diagnostyce złamań żeber i mostka ma już swoje potwierdzenie w piśmiennictwie. Celem pracy było zaprezentowanie opisu dwóch przypadków, w których ultrasonografia była istotną składową procesu diagnostycznego. Przedyskutowano miejsce ultrasonografii klatki piersiowej w diagnostyce złamań żeber i mostka. W podsumowaniu autorzy zamieścili następujące wnioski: 1) badanie było proste do przeprowadzenia i oceny oraz prowadziło do przydatnych klinicznie wniosków; 2) dzięki mobilności aparatu USG badanie może być przeprowadzane poza oddziałami radiologii, np. przy łóżku pacjenta - na oddziałach chirurgii; 3) ultrasonografia to badanie, które powinno być przeprowadzone $u$ wszystkich chorych po urazie klatki piersiowej i z powodzeniem może być wykonywane przez lekarzy niebędących radiologami.

Słowa kluczowe: ultrasonografia, złamania żeber, złamanie mostka, odma opłucnowa.

Hospital in Sieradz, Poland. Both patients were admitted to the department with history of chest trauma. As well as routine radiography, chest ultrasound examinations were performed. The ultrasound examinations were compared with other, routinely used imaging methods as well as with clinical examinations.

In all US examinations, the ultrasound machine was equipped with a 9-Mhz linear probe. M-mode function was not available in the ultrasound machine used by the examiners.

None of the personnel performing the US examinations were radiologists.

\section{Case study 1}

A 54-year-old male patient was admitted to the Department of Diabetology and Internal Medicine of the Wyszynski Memorial Hospital in Sieradz because of hypertension, hypoglycaemia, and general fatigue. Two weeks before admission the patient experienced trauma to the chest. 
In the routinely performed chest $X$-ray (PA) pneumothorax $(3 \mathrm{~cm})$ and a single round shadow $(1.6 \mathrm{~cm}$ in diameter) were revealed in the area of the left lung (Fig. 1). After a surgical consultation, the patient was transferred to the Department of Surgery and qualified for chest drainage. UItrasound examination performed by employees of the Department of Surgery ( $A B$ and $A P$ ) revealed fractures of four ribs - II (Fig. 2), III (Fig. 3), IV, and V, as well as signs of pneumothorax. Additionally, a lesion, about $1.6 \mathrm{~cm}$ in size, was found on the fourth rib in the midclavicular line (Fig. 4), i.e. in the same location and with the same size as the single round shadow visible on the chest radiogram. After placement of drainage, the patient reported strong improvement in breathing. Radiological diagnostics performed after the procedure confirmed that the single round shadow was a lesion on the fourth rib. On the X-ray images that were obtained later (PA and oblique projection) the anterior parts of the ribs were invisible, and only the fracture of the fifth rib, which was placed in the posterior axillary line, was

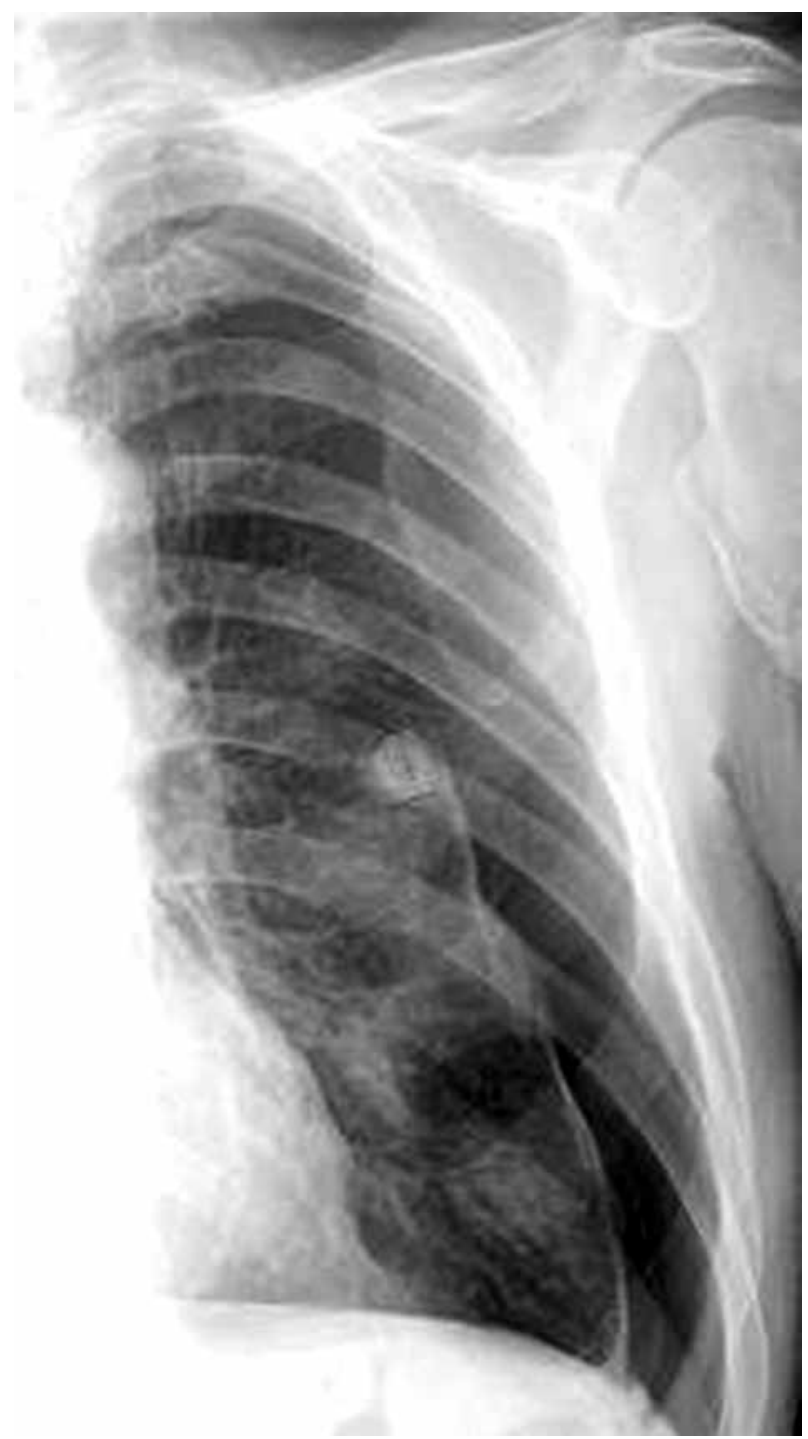

Fig. 1 . In routinely performed chest X-ray (PA), pneumothorax $(3 \mathrm{~cm})$ and a single round shadow $(1.6 \mathrm{~cm}$ in diameter) were revealed in the area of the left lung confirmed. Notwithstanding, the rib fractures were clinically obvious (strong pain during palpation, movements of the fracture components during palpation, subtle deformation of the left side of the rib cage). Five days later, control US demonstrated small left-sided pneumothorax. The finding was confirmed on X-ray (Fig. 5).

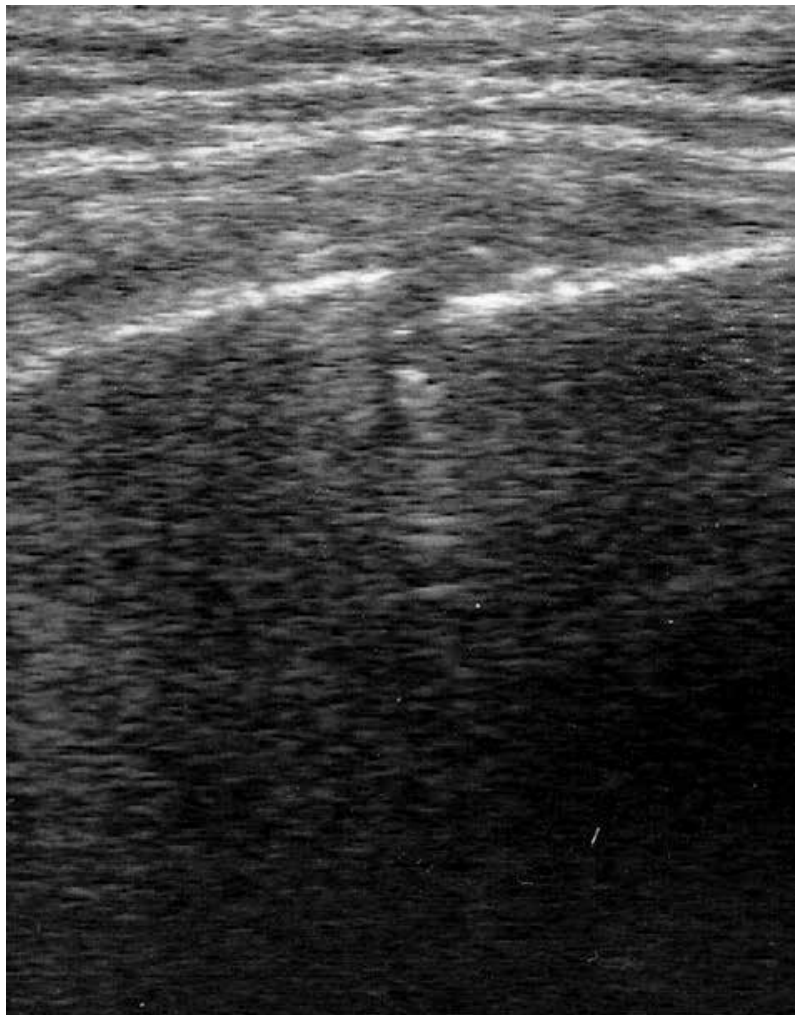

Fig. 2. Fracture of the $2^{\text {nd }}$ rib

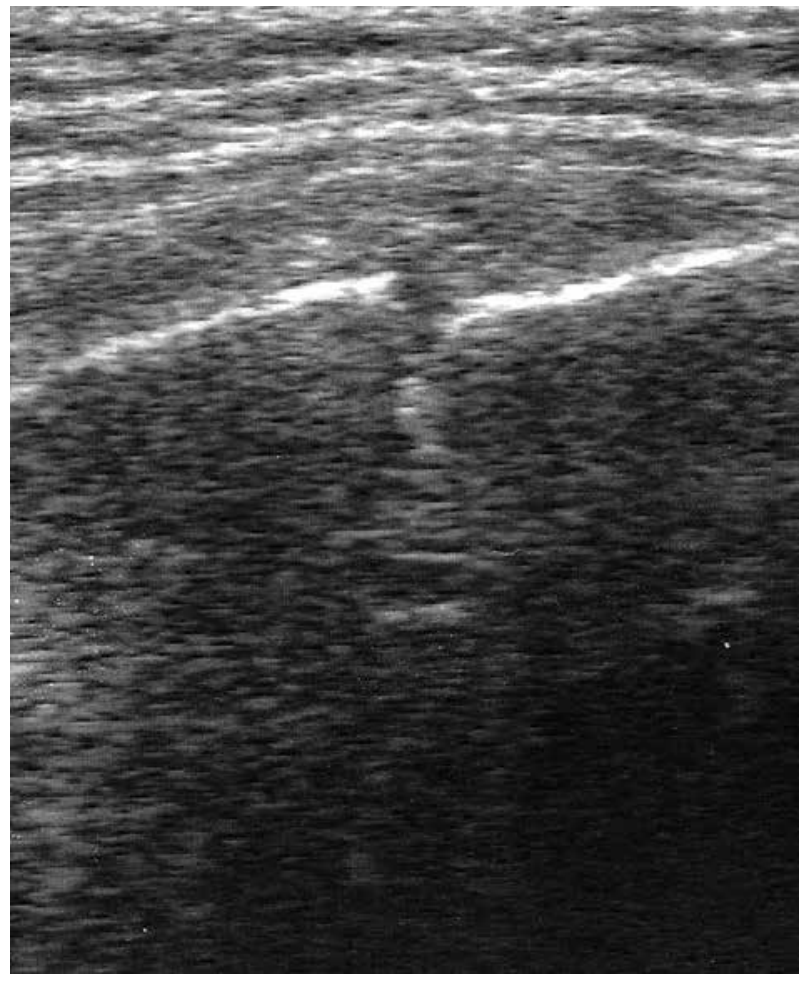

Fig. 3. Fracture of the $3^{\text {rd }}$ rib 


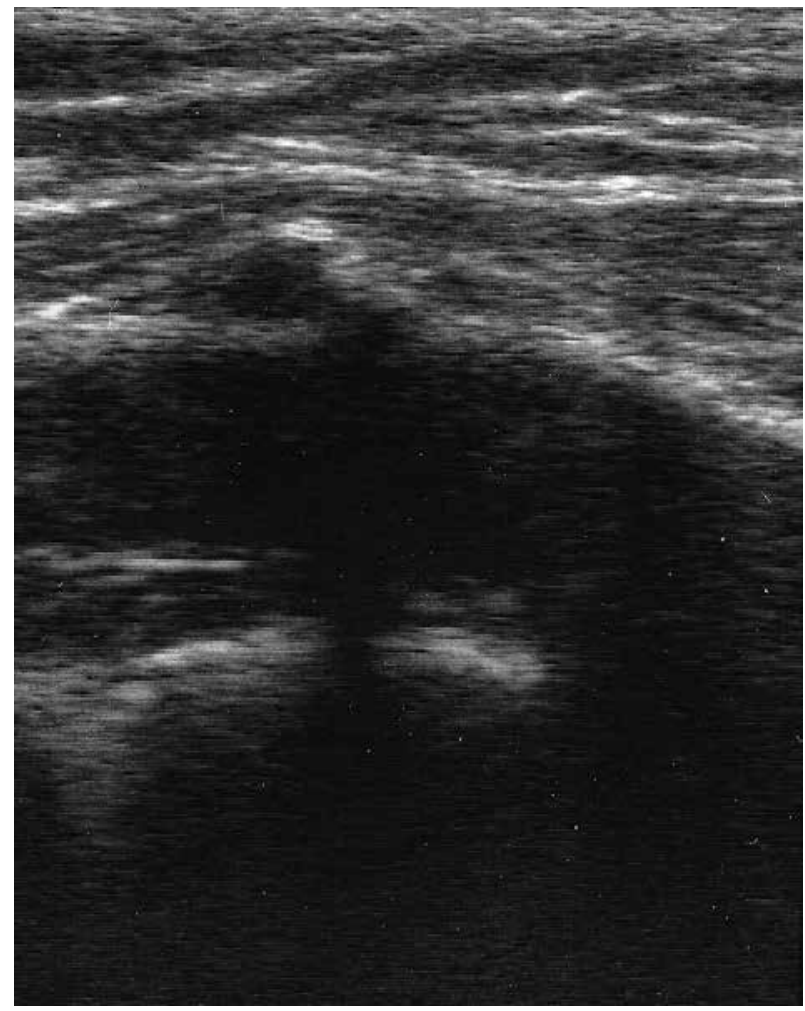

Fig. 4. A 1.6-cm lesion on the $4^{\text {th }}$ rib in the midclavicular line

On the seventh day, when the absence of pneumothorax was confirmed by US, a control X-ray examination was planned.

The result of the US examination was confirmed, and the chest tube was removed.

\section{Case study 2}

The 25-year-old male patient was admitted to the Department of Surgery because of chest trauma resulting from gymnastic exercises performed by the patient on the day of admission. He suffered from chest pain and dyspnoea.

Clinical examination revealed invagination of the manubrium of the sternum with pain during compression; respiratory sounds were symmetrical, heart rate was regular, and the abdomen was soft and painless, without visible signs of trauma.

The result of X-ray examination of the sternum (Fig. 6) was unclear - the radiologist only "suggested" the presence of a sternal fracture.

On the US image, the fracture was evident; moreover, movements of the fracture components during respiration were visible (Figs. 7 and 8). The ultrasound revealed no rib fractures, pneumothorax, or pleural effusion.

The patient was treated conservatively.

\section{Discussion}

According to the $12^{\text {th }}$ edition of the U.S. Report on Carcinogens, exposure to $\mathrm{X}$-ray and gamma radiation is associ-

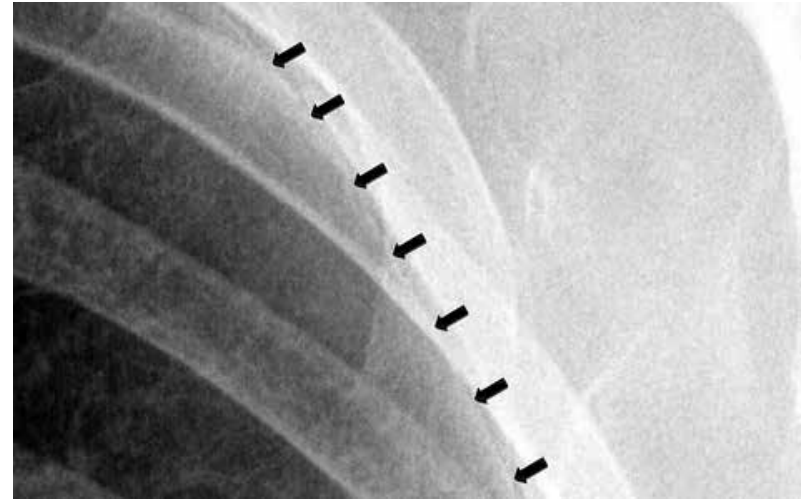

Fig. 5. X-ray image showing small pneumothorax

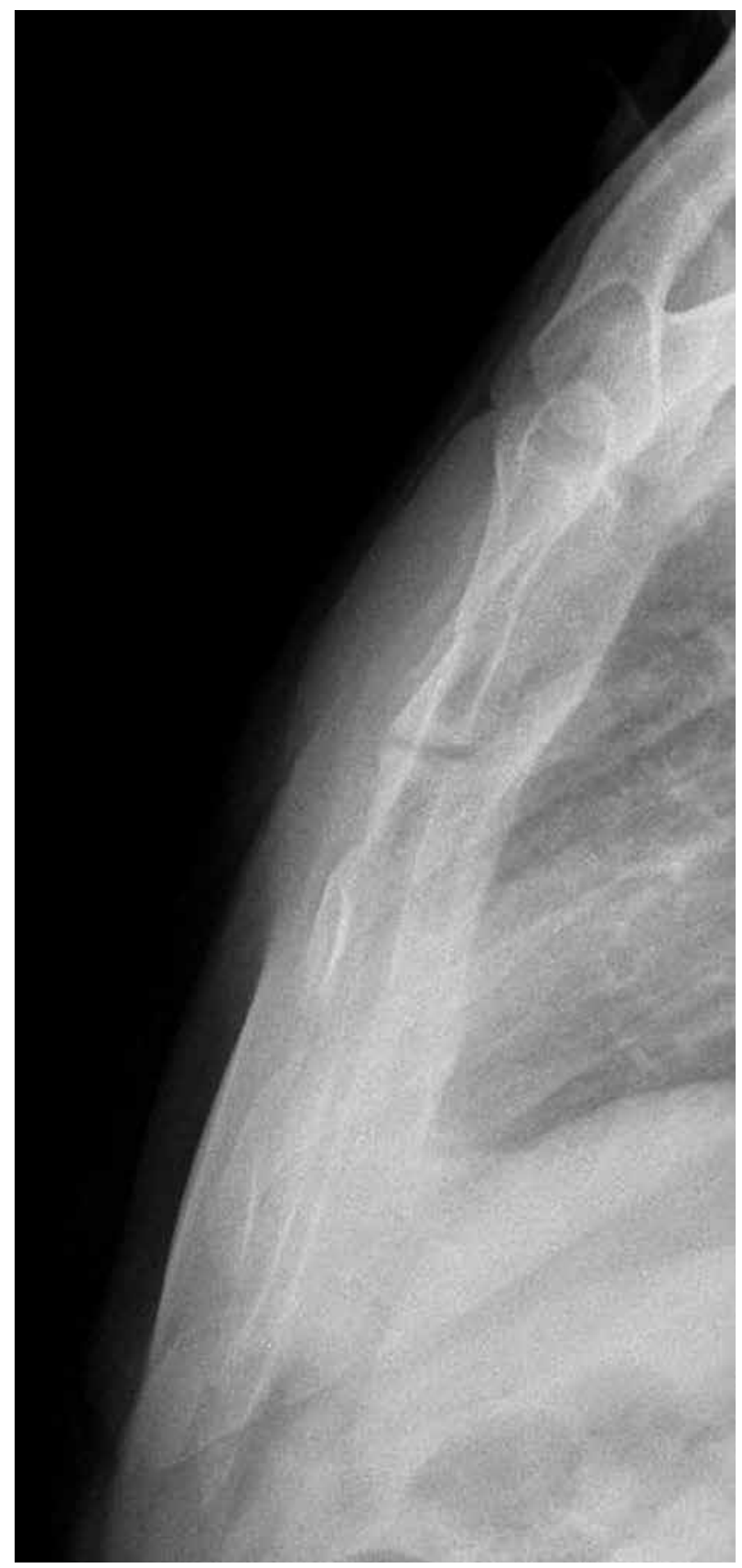

Fig. 6. X-ray of the sternum and the "suggested" sternal fracture 


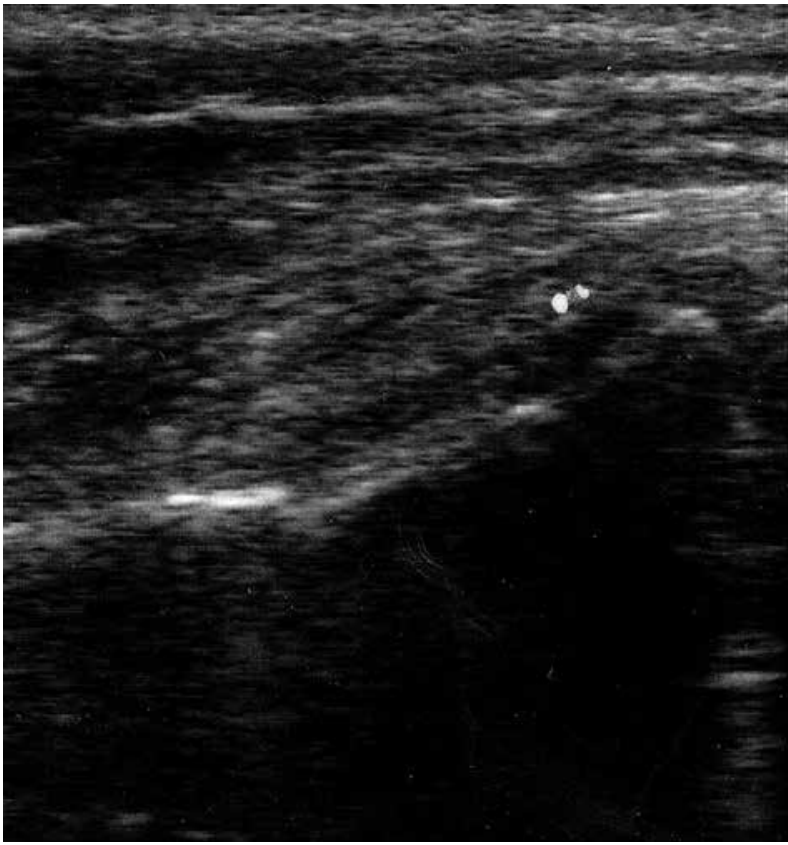

Fig. 7. Fracture of the sternum in ultrasound (US)

ated with leukaemia and cancer of the thyroid, breast, and lung [1].

The effects of exposure to X-rays are probably cumulative and should be avoided whenever possible [2]. Therefore, there is a strong need in modern medicine to find new opportunities for using non-ionising diagnostic methods.

The usefulness of ultrasound imaging in rib and sternal fractures is well documented in literature. Rib fractures were the first bone fractures assessed by ultrasound. The first study was published as far back as 1990 by Smeets et al. [3]. Later, many authors reported that rib fractures were more visible on US images than on standard radiograms [4-10]. According to Griffith et al., X-ray examinations revealed $12 \%$ of rib fractures, whereas ultrasound revealed $78 \%$ [9]. In our first case, the rib fractures were not evidently shown by routine imaging and constituted a diagnostic challenge. This is why US was the key examination in the diagnosis of rib fractures in that case. In addition, the ultrasound was very useful for the differential diagnosis of the single round lung shadow, which was in fact a lesion on the fourth rib. In short, the ultrasound examination was helpful in reaching the final diagnosis and determining the optimal course of action.

The effectiveness of US in diagnosing sternal fractures was also reported in literature [5, 11-15]. In our second case, the result of the $\mathrm{X}$-ray examination, assessed by a radiologist, was unsatisfactory from the clinical point of view only a suggestion of a possible fracture was included in the report. On the US image the fracture became evident; moreover, movements of the fracture components during respiration were visible.

The high sensitivity and specificity of transthoracic ultrasound in the detection of pneumothorax has also been well documented. Moreover, the technique is said to be su-

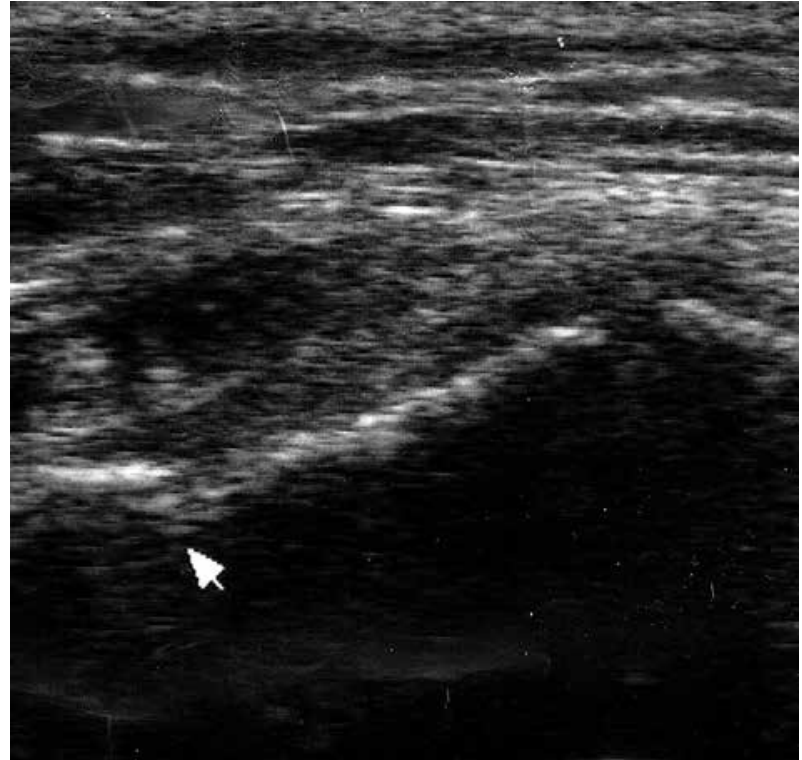

Fig. 8. Fracture of the sternum in ultrasound (US)

perior to standard chest radiography in diagnosing pneumothoraces in patients after blunt chest trauma. According to Fisher's Mastery of Surgery ( $5^{\text {th }}$ edition), transthoracic ultrasound should be performed routinely after chest trauma [16]. In a study by Soldati et al. ultrasound had sensitivity of $92 \%$, while standard radiographs revealed only $52 \%$ of pneumothoraces [17]. In the first case, the ultrasound examination was useful in assessing the progress in the treatment of pneumothorax and determining the times of control X-ray and chest drainage removal.

Chest ultrasound is rarely discussed in Polish literature, especially with regard to the diagnosis of rib and sternal fractures. The use of US in the diagnostic process after chest trauma in Poland is unusual, especially in hospitals outside academic centres. The examination is easy to perform, and, considering its advantages and the benefits it offers, more studies about it should be published to popularise the knowledge of the opportunities provided by ultrasound in the hands of surgeons.

\section{Conclusions}

The examination was easy to perform and assess, and provided clinically useful conclusions.

Due to the mobility of the ultrasound machine, the examination may be carried out outside of radiology departments, e.g. by the patient's bedside - in departments of surgery.

The ultrasound should be the examination of choice after chest trauma and can be performed successfully by non-radiologist physicians.

\section{Disclosure}

Authors report no conflict of interest. 


\section{References}

1. U.S. Department of Health and Human Services. Public Health Service. National Toxicology Program Report on Carcinogens. Twelfth Edition 2011; 237-240.

2. Williamson D, Watura R, Cobby M. Ultrasound imaging of forearm fractures in children: a viable alternative? J Accid Emerg Med 2000; 17: 22-24.

3. Smeets AJ, Robben SG, Meradji M. Sonographically detected costochondral dislocation in an abused child: a new sonographic sign to the radiological spectrum of child abuse. Pediatr Radiol 1990; 20: 566-567.

4. Battistelli JM, Anselem B. Echography in injuries of costal cartilages. J Radiol 1993; 74: 409-412.

5. Bitschnau R, Gehmacher O, Kopf A, Scheier M, Mathis G. Ultrasound diagnosis of rib and sternum fractures. Ultraschall Med 1997; 18: 158-161.

6. Mariacher-Gehler S, Michel BA. Sonography: a simple way to visualize rib fractures. AJR Am J Roentgenol 1994; 163: 1268.

7. Wischhöfer E, Fenkl R, Blum R. Ultrasound detection of rib fractures for verifying fracture diagnosis. A pilot project. Unfallchirurg 1995; 98: 296-300.

8. Wüstner A, Gehmacher O, Hämmerle S, Schenkenbach C, Häfele H, Mathis G. Ultrasound diagnosis in blunt thoracic trauma. Ultraschall Med 2005; 26: 285-290.

9. Griffith JF, Rainer TH, Ching AS, Law KL, Cocks RA, Metreweli C. Sonography compared with radiography in revealing acute rib fracture. AJR Am J Roentgenol 1999; 173: 1603-1609.
10. Koegelenberg CF, Diacon AH, Bolliger CT. Transthoracic ultrasound for chest wall, pleura, and the peripheral lung. In: Clinical Chest Ultrasound. From the ICU to the Bronchoscopy Suite. Karger, Basel 2009; pp. 23.

11. Mahlfeld A, Franke J, Mahlfeld K. Ultrasound diagnosis of sternum fractures. Zentralbl Chir 2001; 126: 62-64.

12. Fenkl R, Von Garrel T, Knapler H. Emergency diagnosis of sternum fracture with ultrasound. Unfallchirurg 1992; 95: 375-379.

13. Hendrich C, Finkewitz U, Berner W. Diagnostic value of ultrasonography and conventional radiography for the assessment of sternal fractures. Injury 1995; 26: 601-604.

14. Engin G, Yekeler E, Guloglu R, Acunaş B, Acunaş G. US versus conventional radiography in the diagnosis of sternal fractures. Acta Radiol 2000; 41: 296299.

15. You JS, Chung YE, Kim D, Park S, Chung SP. Role of sonography in the emergency room to diagnose sterna fractures. J Clin Ultrasound 2010; 38: 135137.

16. Fisher JE, Bland KI (eds.). Mastery of Surgery. Lippincott, Williams \& Wilkins, Philadelphia 2011; 103.

17. Soldati G, Testa A, Sher S, Pignataro G, La Sala M, Silveri NG. Occult traumatic pneumothorax: diagnostic accuracy of lung ultrasonography in the emergency department. Chest 2008; 133: 204-211. 